(c) American Dairy Science Association, 2004.

\title{
Hyperimmunization of Steers with J5 Escherichia coli Bacterin: Effects on Isotype-Specific Serum Antibody Responses and Cross Reactivity with Heterogeneous Gram-Negative Bacteria
}

\author{
A. Chaiyotwittayakun, ${ }^{1,2}$ J. L. Burton, ${ }^{2}$ P. S. D. Weber, ${ }^{2}$ K. Kizilkaya, ${ }^{2}$ \\ F. F. Cardoso, ${ }^{2}$ and R. J. Erskine ${ }^{1}$ \\ ${ }^{1}$ Department of Large Animal Clinical Sciences and \\ ${ }^{2}$ Department of Animal Science, Michigan State University, \\ East Lansing, 48824
}

\begin{abstract}
Isotype-specific antibody responses and cross reactivity were profiled following hyperimmunization of steers with J5 Escherichia coli bacterin. The vaccine was administered at time 0, $30 \mathrm{~d}$ later, and every $2 \mathrm{wk}$ for 10 subsequent immunizations. Blood was collected preimmunization and multiple times following each immunization. Isotype-specific anti-J5 Escherichia coli antibody response profiles in diluted sera harvested from each sample were assayed by ELISA and recorded as optical density. Selected sera were assayed for anti-J5 Escherichia coli antibody titers and used to determine cross reactivity against a variety of gram-negative bacteria. Immunization number and day postimmunization influenced response profiles for anti-J5 E. coli IgM, $\mathrm{IgG}_{1}$ and $\mathrm{IgG}_{2}$ antibodies. Two immunizations increased mean serum IgM and the $\operatorname{IgG}_{1}$ antibody profiles above preimmunization levels, but 5 immunizations were required to detect significant $\mathrm{IgG}_{2}$ antibody responses that were above preimmunization levels. Isotype-specific cross reactivity of the serum antibodies with a variety of heterologous gram-negative bacteria was also increased by hyperimmunization. However, no cross reactivity was observed for Staphylococcus aureus, purified lipopolysaccharide, or lipid A. Our results indicate that multiple booster doses of J5 E. coli bacterin may be required to elicit high levels of cross-reactive serum $\mathrm{IgG}_{2}$ antibodies.
\end{abstract}

(Key words: J5 Escherichia coli, hyperimmunization, antibody response, cross reactivity)

Abbreviation key: FBS = fetal bovine serum, INF$\gamma=$ interferon-gamma, $\mathbf{O D}=$ optical density, $\mathbf{O M P}=$ outer membrane protein, TSB = trypticase soy broth.

Received August 12, 2003.

Accepted March 23, 2004.

Corresponding author: R. J. Erskine; e-mail: erskine@cvm. msu.edu.

\section{INTRODUCTION}

Immunization of cattle with J5 Escherichia coli bacterin has been used as a method to enhance immune resistance against gram-negative bacteria, including mastitis-causing coliforms. Commercial J5 bacterins contain a mutant stain of $E$. coli $0111: B 4$ (Rc mutant) lacking the "O" antigen capsular portion of the bacterial cell wall but with core LPS and lipid A antigens intact. These core antigens are highly conserved across all gram-negative bacteria (Gonzalez et al., 1989; Tyler et al., 1990b; Cullor, 1991) and are thus considered as being primarily responsible for eliciting cross-reactive antibodies in J5 vaccinated cows (Tyler et al., 1990a; 1992; Tomita et al., 1995).

Some studies have reported that cows vaccinated with J5 bacterin using the manufacturer's recommended protocols have relatively adequate IgM and total IgG antibody responses in serum and milk (Tyler et al., 1991, 1992; Tomita et al., 1995). However, only a few studies have monitored responses of the main opsonizing antibody in J5 immunized cattle, namely $\mathrm{IgG}_{2}$. In 2 such studies, J5 E. coli-specific $\mathrm{IgG}_{2}$ antibodies were increased modestly in conventionally vaccinated dairy cows vs. unvaccinated cows, but the vaccinated animals were not protected from experimental coliform mastitis (Hill, 1991; Tomita et al., 2000). This may have been due to the dose of bacteria used for the experimental infections or an indication that the serum antibody responses elicited by recommended use of J5 bacterins were not strong enough to be protective, even though they were detectable.

Gram-negative bacterins have traditionally been labeled as weakly immunogenic in cattle because they elicit relatively poor anemnestic $\left(\mathrm{IgG}_{1}\right.$ and $\left.\mathrm{IgG}_{2}\right)$ antibody responses (reviewed by Kehrli and Harp, 2001). Published studies exploring the potential of improving $\mathrm{IgG}_{1}$ and $\mathrm{IgG}_{2}$ immune responses using $\mathrm{J} 5$ dosing protocols different from those currently recommended by vaccine manufacturers are scarce. To our knowledge, no studies have been published in which the goal was 
to optimize the J5 $E$. coli immunization schedule to maximize serum antibody concentrations in cattle. This was one objective of the current study. In light of the key role as an opsonin that $\mathrm{IgG}_{2}$ plays in efficient clearance of invading pathogens by bovine neutrophils (McGuire et al., 1987; Burton and Erskine, 2003), the second objective of this study was to determine whether J5 bacterin elicits gram-negative cross-reactive $\mathrm{IgG}_{2}$ antibodies. Based on the notion that J5 E. coli bacterins are lowly immunogenic, our hypothesis was that multiple booster doses of commercial J5 vaccine would be needed to elicit strong serum $\mathrm{IgG}_{1}$ and $\mathrm{IgG}_{2}$ antibody responses that cross-react well with heterologous gramnegative bacteria.

\section{MATERIALS AND METHODS}

\section{Animals}

Five 5-mo old Holstein steers were used for this study. Steers were owned by a private dairy in Michigan, and housed and cared for at the farm for the duration of the study. Animals were group-housed with free access to water and feed. In preparation for entry into our study, the animals were immunized twice for bovine viral diarrhea, infectious bovine rhinotracheitis, parainfluenza 3 , bovine respiratory syncytial virus, and 5 serovars of Leptospira (triangle 9; Fort Dodge Animal Health, Fort Dodge, IA), and dewormed (Ivermec, Merck \& Co., Inc., Rahway, NJ) at 3 mo of age (i.e., before the trial). All steers were deemed healthy at the start of the study, and remained healthy throughout the study.

\section{Immunization Schedule}

All experimental animals entered the trial, were immunized and bled on the same days. A total of $12 \mathrm{immu-}$ nizations were administered to each steer by subcutaneous injection of 5-mL doses of a commercially available vaccine (J5 E. coli bacterin; Pharmacia Animal Health, Kalamazoo, MI). The first immunization was administered at study time 0 . The second immunization was administered $30 \mathrm{~d}$ later. The subsequent $10 \mathrm{immu}-$ nizations were administered every $2 \mathrm{wk}$, with the exception of an 8-wk rest period between the sixth and seventh immunizations. This was done because the PCV of the steers had decreased after the sixth, bleeding to the point where it was considered necessary to suspend bleeding to insure anemia did not develop.

Blood was collected from each steer immediately before the first immunization (preimmunization), on $\mathrm{d} 4$, 6 , and 11 postimmunization for doses 1 through 6 , and on $\mathrm{d} 4,6,11$, and 13 postimmunization for doses 7 through 12 . The additional blood sample was collected on $\mathrm{d} 13$ postimmunization for the last 6 doses to maximize the harvest of serum antibodies for isolation and purification. Blood samples $(150 \mathrm{~mL})$ were collected from the jugular vein into $50-\mathrm{mL}$ sterile conical centrifuge tubes using 14 gauge, 3.75 -cm needles. Samples were allowed to clot overnight at $4^{\circ} \mathrm{C}$ and were then centrifuged $\left(2400 \times \mathrm{g}\right.$ for $30 \mathrm{~min}$ at $\left.4^{\circ} \mathrm{C}\right)$ for sera harvesting. Sera were stored in $\sim 25$ - $\mathrm{mL}$ aliquots at $-20^{\circ} \mathrm{C}$ until assayed by ELISA.

\section{Preparation of J5 E. coli Whole Cell Antigen for Use in ELISA}

J5 E. coli (0111:B4, Rc mutant; donated by James Cullor, University of California, Davis, CA) was plated on 5\% sheep blood agar and incubated overnight at $37^{\circ} \mathrm{C}$. The plate was checked for culture purity and single colonies from pure cultures selected and inoculated in $15 \mathrm{~mL}$ of trypticase soy broth (TSB) for overnight culture at $37^{\circ} \mathrm{C}$ in an orbital shaker (120 rpm; J. T. Baker, Phillipsburg, NJ). To establish purity of the cultures, $10-\mu \mathrm{L}$ aliquots were collected from each inoculum and plated on 5\% sheep blood agar overnight at $37^{\circ} \mathrm{C}$. The cultures were stored at $4^{\circ} \mathrm{C}$ during this incubation. If the overnight cultures proved to be pure, each culture was transferred into $1 \mathrm{~L}$ of TSB and incubated while shaking at $120 \mathrm{rpm}$ for $18 \mathrm{~h}$ at $37^{\circ} \mathrm{C}$. These preparations were then stored at $4^{\circ} \mathrm{C}$ while purity was assured by culture, and the pure bacteria were killed by adding $15 \mathrm{~mL}$ of a $99 \%$ liquid phenol solution (Sigma Chemical, St. Louis, MO) per liter of the bacterial preparation. This solution was incubated with shaking for 1 $\mathrm{h}$ at $37^{\circ} \mathrm{C}$ and $120 \mathrm{rpm}$. The phenol-killed whole cell bacteria were centrifuged $\left(1000 \times g\right.$ for $12 \mathrm{~min}$ at $\left.4^{\circ} \mathrm{C}\right)$, pellet washed twice in $500 \mathrm{~mL}$ of sterile $0.9 \% \mathrm{NaCl}$, and suspended in the same to an optical transmission of $13 \%\left(\sim 1 \times 10^{9} \mathrm{cfu} / \mathrm{mL}\right)$ using a spectrophotometer (model DU 650; Beckman Coulter, Inc., Fullerton, CA). This whole cell J5 antigen solution was stored in 12$\mathrm{mL}$ aliquots at $-20^{\circ} \mathrm{C}$ until used in ELISA.

\section{ELISA to Monitor Isotype-Specific Anti-J5 E. coli Antibody Response Profiles}

Serum anti-J5 E. coli $\mathrm{IgM}, \mathrm{IgG}_{1}$, and $\mathrm{IgG}_{2}$ antibody response profiles (Burton et al., 1993) were determined using an ELISA protocol described in Tyler et al. (1990a). Briefly, $100 \mu \mathrm{L}$ of J5 E. coli whole cell antigen was used to coat wells of 96-well ELISA plates (ProBind Flat Bottom plates, Fisher Scientific). Normal saline (100 $\mu \mathrm{L} /$ well) was added to 2 wells of each plate for later blanking during plate reading (see below). Three plates were coated at a time, one for analysis of IgM antibody responses and the other 2 for analysis of Ig- 
$\mathrm{G}_{1}$ and $\mathrm{IgG}_{2}$ antibody responses. The plates were covered and left to incubate on a flat surface at room temperature for $15 \mathrm{~h}$, after which unbound antigen was removed by 6 washes using $200 \mu \mathrm{L} /$ well of biowash solution (0.9\% saline containing $0.05 \%$ Tween 20$)$.

Test sera were prepared for ELISA using separate 96-well, U-bottom polystyrene microtiter plates (Becton Dickinson, Franklin Lakes, NJ). Individual samples were placed in the top well of each column and diluted twofold down the 8 rows of the plate, starting with a 1:50 dilution in row $\mathrm{A}$ and ending with a dilution of 1:6400 in row $\mathrm{H}$. The sample diluent was PBS ( $\mathrm{pH} 7.3)$ with $0.5 \%$ Tween 20 . A positive control consisting of pooled sera from blood samples collected following the 5th immunization was similarly diluted down rows of one column of each plate. The negative control in this assay was fetal bovine serum (FBS, endotoxin $\leq 10 \mathrm{EU} /$ $\mathrm{mL}$; Life Technologies, Rockville, MD) and was diluted in the same fashion in one column of each plate. Additional controls in the assay included quadruplicate wells of premade 1:400 dilutions of the positive and negative control sera, duplicate wells that received only the coating antigen, and duplicate wells that received all reagents except test sample. Samples contained in each well of the dilution plates were transferred (100 $\mu \mathrm{L} /$ well) to washed ELISA plates using a multi-channel pipetter (Costar Corporation, Cambridge, MA).

Once all samples were delivered to appropriate wells, ELISA plates were sealed and incubated at $37^{\circ} \mathrm{C}$ for 45 min. Following incubation, the plates were washed 6 times (as above) and $100 \mu \mathrm{L} /$ well of detection antibody (1:25,000 in sample diluent; horseradish peroxidaseconjugated sheep anti-bovine IgM, IgG 1 , or IgG Ig $_{2}$ B Bethyl Laboratories, Montgomery, TX) added to wells of the appropriate plates. Plates were again sealed and incubated for $30 \mathrm{~min}$ at $37^{\circ} \mathrm{C}$, washed 6 times, and $125 \mu \mathrm{L} /$ well of substrate (hydrogen peroxide-azino-bis-3-ethylbenzthiazoline sulfonic acid; Sigma) added for $45 \mathrm{~min}$ at $37^{\circ} \mathrm{C}$.

The levels of isotype-specific antibodies in the variously diluted samples were recorded as optical density (OD) following spectrometric analysis at dual wavelength (405 nm normalized against $450 \mathrm{~nm}$ ) using an ELISA plate reader (Benchmark, Bio-RAD Laboratories, Hercules, CA). The plate reader was calibrated against the 2 blank wells of each plate before each was read. The IgG $\mathrm{I}_{1}$ antibodies are always highest in concentration in bovine serum (Butler, 1998). We thus used the daily $I_{g} G_{1}$ plates to monitor repeatability of each ELISA performed. We found that the greatest and most repeatable differences in $\mathrm{IgG}_{1}$ OD between the positive and negative control sera always occurred at the 1:400 dilution, whether the control sera were diluted that day or used as the premade controls. Thus, if OD values of the 1:400 dilutions of positive and negative control sera in the $\mathrm{IgG}_{1}$ plate were not within preestablished ranges $(0.99 \leq \mathrm{OD} \leq 1.10$ and $\mathrm{OD} \leq 0.09$, respectively), all samples in each isotype-specific plate were repeated on a subsequent assay day. Once all OD data were acquired for each isotype, antibody response profiles were checked for parallelism across all dilutions used. This was done by correlation analysis using SAS (SAS/STAT, 1999). Parallelism was considered significant when OD profiles of 3 consecutive doubling dilutions of samples within isotype yielded $\mathrm{r}>0.90$ with $P<0.0001$ and resulted in identical response curves over time. According to these criteria, we selected the 1:100 dilution for statistical analysis of the serum IgM anti-J5 E. coli antibody response profile and 1:400 for analysis of the serum $\operatorname{IgG}_{1}$ and $\mathrm{IgG}_{2}$ anti-J5 E. coli antibody response profiles.

\section{Isotype Specific Anti-J5 E. coli Antibody Titers in Selected Serum Samples}

ELISA was used to determine endpoint titers of isotype-specific anti-J5 E. coli antibodies in selected sera. This was done to identify samples to be used in the subsequent antibody cross reactivity experiment (see below). Based on the response profiles already determined by the protocol described above, samples selected for titer analysis were preimmunization and $6 \mathrm{~d}$ post 3rd, 6th, 9th, and 12th immunizations. These sera were serially twofold diluted from 1:4 through 1:131,072 down columns of a series of U-bottom plates per isotype before addition to J5 $E$. coli coated ELISA plates, and the remainder of the ELISA performed as described above (including blanks and controls). Endpoint titers were recorded as the last dilution to yield an OD $>0.09$, which was considered zero-titer because the OD for $\mathrm{IgG}_{1}$ in the 1:400 dilution of FBS was always $<0.09$.

\section{Cross Reactivity of the Isotype-Specific Serum Antibodies Measured by ELISA}

The antibodies in sera from preimmunization and 6 d post-3rd, -6th, -9th, and -12th immunizations were assessed for cross reactivity against multiple heterologous gram-negative antigens by ELISA. The whole cell antigens used contained $\left(\sim 1 \times 10^{9} \mathrm{cfu} / \mathrm{mL}\right.$ of relevant bacteria (i.e., $13 \%$ optical transmissions) and included J5 E. coli as a gram-negative positive control, Staphylococcus aureus as a gram-positive negative control, and E. coli McDonald 487, Pseudomonas ssp., Serratia ssp., Klebsiella ssp., Salmonella newport, and Salmonella typhimurium as test antigens. The $S$. newport and S. typhimurium were donated by the Animal Health Diagnostic Laboratory (Michigan State University, 
East Lansing). The other bacteria originated from milk cultured in our laboratory from cows with clinical mastitis. Each was cultured and killed with phenol to make antigen solutions as described above for J5 E. coli. Purified LPS (from J5 E. coli 0111:B4 Rc mutant; Sigma) and lipid A (monophosphoryl from S. minnesota, Re 595; Sigma), both at $10 \mu \mathrm{g} / \mathrm{mL}$, were prepared as described (Freudenburg et al., 1989) and used as additional antigens for plate coating. Test sera were diluted 1:50 (for $\mathrm{IgG}_{2}$ and IgM) or 1:200 (for $\operatorname{IgG}_{1}$ ) in sample diluent for determining isotype-specific antibody cross reactivity for the test and control antigens, which was recorded as OD.

\section{Cross Reactivity of the Isotype-Specific Serum Antibodies Determined by Immunoblotting}

The various bacteria described above were grown on $5 \%$ sheep blood agar overnight at $37^{\circ} \mathrm{C}$. Single colonies were inoculated in $15 \mathrm{~mL}$ of TSB and incubated while shaking (225 rpm) for $18 \mathrm{~h}$ at $37^{\circ} \mathrm{C}$. Purity of culture was confirmed by overnight culture at $37^{\circ} \mathrm{C}$ on $5 \%$ sheep blood agar. The cultures were centrifuged $(8000 \times g$ for $15 \mathrm{~min}$ at $4^{\circ} \mathrm{C}$ ) to collect bacterial cell pellets, which were then suspended in $3.0 \mathrm{~mL}$ of lysing buffer containing $50 \mathrm{~m} M$ Tris- $\mathrm{HCl}, \mathrm{pH} 7.5,50 \mathrm{~m} M \mathrm{NaCl}, 1 \mathrm{~m} M$ dithiothreitol, and 5\% glycerol. Using a probe sonicator (Sonifier), the bacterial cells were disrupted with multiple short bursts of 15-s pulses with 15-s rests for 1 to 2 min and kept on ice at all times (Harlow and Lane, 1999; Promega, 1996). Resulting crude lysates were cleared of cell debris by centrifugation $(10,000 \times g$ for $15 \mathrm{~min}$ at $4^{\circ} \mathrm{C}$ ). Trichloroacetic acid was added to reconstitute the pellet to a final concentration of $10 \%(\mathrm{wt} /$ vol) and placed on ice for 5 min to precipitate proteins (Promega, 1996). The TCA-treated mixture was centrifuged $\left(12,000 \times g\right.$ for $2 \mathrm{~min}$ at $\left.4^{\circ} \mathrm{C}\right)$ to collected the protein pellets, which were washed twice $(12,000 \times \mathrm{g}$ for 2 min at $4^{\circ} \mathrm{C}$ ) and suspended in ice cold $0.9 \%$ sterile $\mathrm{NaCl}$. Protein concentrations were determined spectrophotometrically $(\lambda=260,280$, and $320 \mathrm{~nm})$ and stored at $-20^{\circ} \mathrm{C}$ until used for immunoblotting.

Sodium dodecyl sulfate-PAGE was used to separate antigens contained in the crude bacterial lysates based on molecular weight. Precision Plus All Blue (size range 10 to $250 \mathrm{kDa}$; BioRad) was the molecular weight marker used on all gels. Bacterial lysates (5 $\mu \mathrm{g}$ each) were prepared using a 1:2 ratio of sample in loading buffer, which was $95 \%$ ( $\mathrm{vol} / \mathrm{vol}$ ) of Laemmli sample buffer (BioRad) that contained $5 \%$ (vol/vol) $\beta$-mercaptoethanol (Sigma Chemical Co., St Louis, MO). The mixed samples were heat-denatured at $95^{\circ} \mathrm{C}$ for $4 \mathrm{~min}$ and placed on ice prior to loading on precast Tris- $\mathrm{HCl}$ polyacrylamide gels $(12.0 \%, 160 \times 160 \times 0.75 \mathrm{~cm}$; BioRad $)$.
The electrophoresis buffer consisted of $1 M$ Tris/glycine/ SDS, pH 8.3. Separated proteins were transferred (Trans-Blot Cell with plate electrode, BioRad) to nitrocellulose membranes ( $0.45 \mu \mathrm{m}$; Pierce, Rockford) at $25 \mathrm{~V}$ (PowerMac 300, BioRad) for $6 \mathrm{~h}$ at $4^{\circ} \mathrm{C}$. The membranes were incubated in Super Blocking buffer in Tris (Pierce) that contained $0.1 \%$ added Tween 20 for $1 \mathrm{~h}$ at room temperature, and were then probed with diluted (1:1000 in sterile milli-Q water) test sera (pooled across the 5 steers from samples collected $6 \mathrm{~d}$ post $3 \mathrm{rd}$ or 9 th immunization). After a 60 -min incubation at room temperature, the blots were washed 6 times [BupH Tris Buffer Saline (Pierce) containing 0.05\% Tween 20] and probed further with anti-bovine HRPO-conjugated isotype-specific detection antibodies $\left(\mathrm{IgM}, \mathrm{IgG}_{1}\right.$, or $\mathrm{IgG}_{2}$, heavy chain specific, Bethyl Laboratories, Inc., Montgomery, TX) for $60 \mathrm{~min}$ at room temperature. After 6 more washes, substrate was added (Super Signal West Pico Chemiluminescent Substrate system; Pierce) for 5 min and the membranes exposed to X-ray film (Kodak BioMax MS; Fisher Scientific) for 2 min. Films were developed (Futura $2000 \mathrm{E}$ Automatic X-Ray film processor; Fischer Industries Inc., Geneva, IL) and photographed (Gel Doc 2000 Fluor-S MultiImager; BioRad) for data presentation.

\section{Statistical Analyses}

The OD data from the antibody profiling experiment were normally distributed and thus analyzed statistically without transformation. For statistical analyses of these data, immunization number and sample day nested within immunization number were included in a mixed model as fixed effects along with assay day, assay plate nested within assay day, and animal as random effects. In addition, autoregressive order one covariance structure (based on Schwarz' Bayesian model-fit criterion) was specified in the REPEATED statement of a model covariance structure (SAS/STAT, 1999) within animal. Statistical differences in isotypespecific mean OD over days following each immunization, and specific differences between the mean immunization number OD for immunizations 1 through 3 versus the preimmunization mean $\mathrm{OD}$, and for immunizations 4 through 12 vs. immunization 3, were analyzed using LSMEAN and ESTIMATE statements of SAS (SAS/STAT, 1999) with Tukey-Kramer adjustment and declared significant when $P \leq 0.05$.

Repeated measures analysis of variance was used to analyze the isotype-specific anti-J5 E. coli $\mathrm{IgM}, \mathrm{IgG}_{1}$, and $\mathrm{IgG}_{2}$ end-point titer and cross reactivity data sets. The end-point titer data were $\log _{2}$-transformed prior to statistical analyses to normalize distributions, but the cross reactivity data (as OD) were normally distributed 


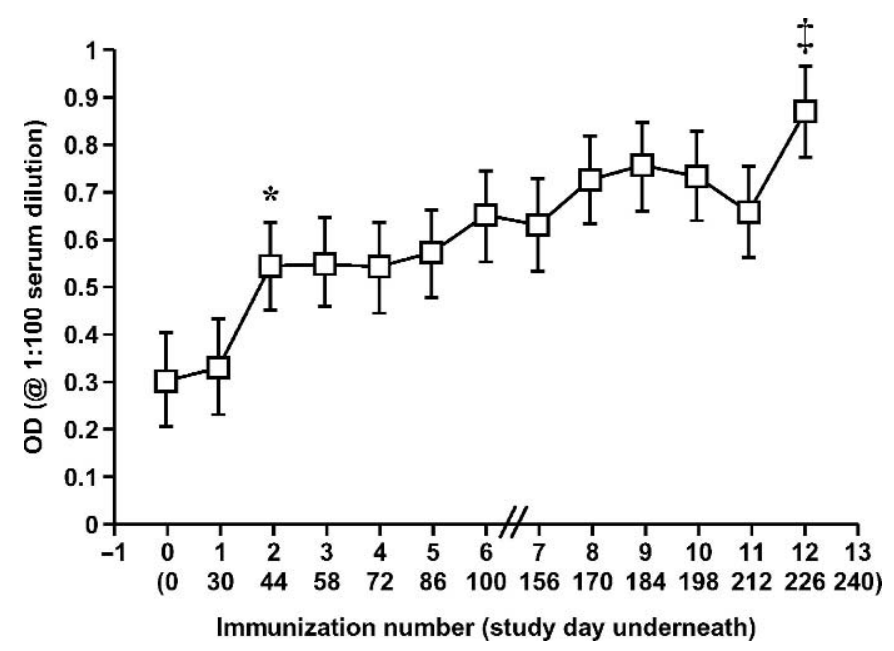

Figure 1. Mean serum anti-J5 Escherichia coli IgM antibody response profile for 5 Holstein steers immunized 12 times with J5 bacterin. Each data point is an immunization number LSMean $( \pm$ SEM) from sera collected either on d 4, 6, and 11 post immunization (first 6 immunizations) or on d 4, 6, 11, and 13 postimmunization (last 6 immunizations), expressed as optical density (OD \pm SEM) when sera were diluted 1:100. *Indicates the point at which mean OD was significantly higher than the preimmunization mean $(P \leq$ $0.05)$. $\ddagger$ Indicates the point at which mean OD was significantly higher than after the third immunization $(P \leq 0.03)$.

and thus analyzed without transformation. Both analyses were carried out utilizing the MIXED procedure of SAS (SAS/STAT, 1999). Main effects in the model included immunization number for the titer data, and antigen and the interaction of antigen $\times$ immunization number for cross reactivity data, and were assessed using the Type III F-test. Differences between TukeyKramer adjusted LSMeans from this analysis were assessed by $t$-test and declared significant when $P \leq 0.05$.

\section{RESULTS}

\section{Isotype-Specific Anti-J5 E. coli Antibody Response Profiles}

Day postimmunization significantly $(P<0.02)$ influenced anti-J5 E. coli $\operatorname{IgM}, \operatorname{IgG}_{1}$, and $\mathrm{IgG}_{2}$ antibody responses (not shown). While no differences in mean OD between sampling days were observed following immunizations 1 to 3 or 8 to 12 , all other immunizations had highest mean OD either on the 11th day postimmunization (for the 4th, 5th, and 6th doses) or on the 6th and 11 th days postimmunization (for the 7 th dose). Animal did not contribute $(P>0.10)$ to variation in mean antibody response profiles. On the other hand, immunization number significantly affected $(P<0.0001)$ mean anti-J5 E. coli $\operatorname{IgM}, \operatorname{IgG}_{1}$, and $\operatorname{IgG}_{2}$ antibody responses, which all increased with increasing immunization number (Figures 1 to 3 ).

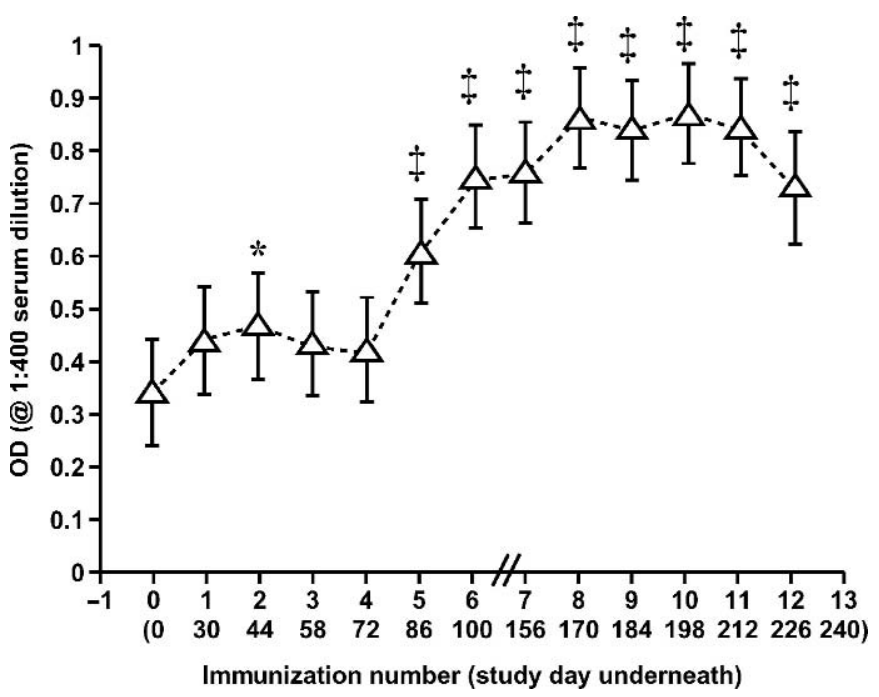

Figure 2. Mean serum anti-J5 Escherichia coli IgG $_{1}$ antibody response profile of 5 Holstein steers immunized 12 times with a J5 bacterin. Each data point is an immunization number LSMean $( \pm$ SEM) from sera collected either on d 4, 6, and 11 postimmunization (first 6 immunizations) or on d 4, 6, 11, and 13 postimmunization (last 6 immunizations), expressed as optical density (OD \pm SEM) when sera were diluted 1:400. *Indicates the point at which mean OD was significantly higher than the preimmunization mean $(P=$ $0.004)$. $\ddagger$ Indicates the point at which mean OD was significantly higher than after the third immunization $(P \leq 0.02)$.

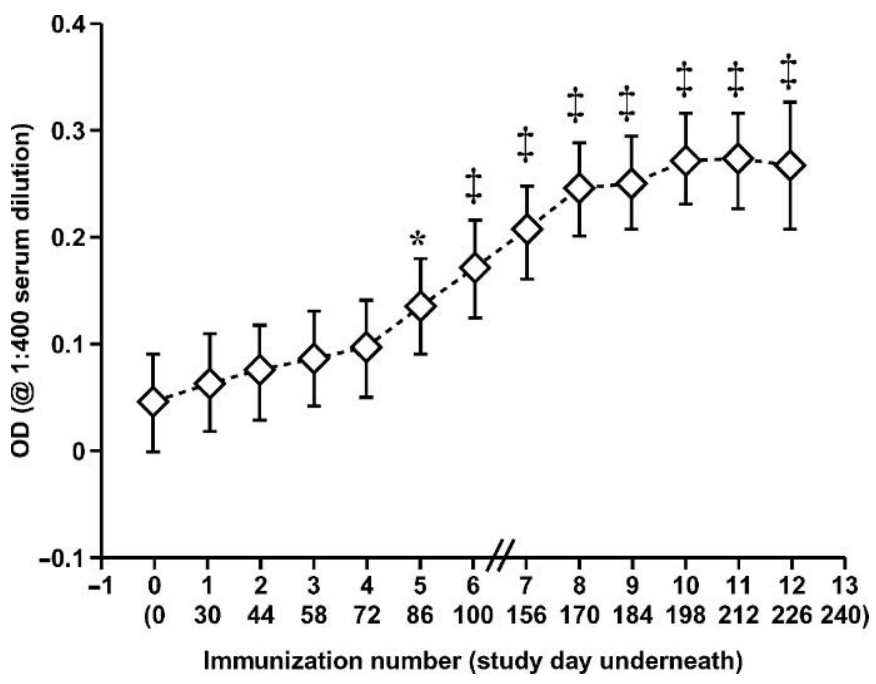

Figure 3. Mean serum anti-J5 Escherichia coli IgG $_{2}$ antibody response profile for 5 Holstein steers immunized 12 times with a J5 bacterin. Each data point is an immunization number LSMean ( \pm SEM) from sera collected either on d 4, 6, and 11 postimmunization (first 6 immunizations) or on d 4, 6, 11, and 13 postimmunization (last 6 immunizations), expressed as optical density (OD \pm SEM) when sera were diluted 1:400. *Indicates the point at which mean OD was significantly higher than the preimmunization mean $(P=$ $0.004)$. + Indicates the point at which mean OD was significantly higher than after the 3rd immunization $(P \leq 0.001)$. 
Adjusted differences in mean OD between immunization numbers revealed that only 2 doses of J5 bacterin were required to significantly $(P \leq 0.05)$ increase serum anti-J5 E. coli IgM above preimmunization levels (Figure 1). The IgM response reached a plateau after the second immunization but a sudden increase in the response was observed following the 12th immunization. Like IgM, 2 doses of J5 bacterin were enough to elicit a significant $(P=0.004)$ increase in the anti-J5 E. coli $\mathrm{IgG}_{1}$ antibody response above that observed preimmunization (Figure 2). The $\operatorname{IgG}_{1}$ response then increased ( $P$ $\leq 0.02$ ) between the fifth and eighth immunizations, after which it reached a plateau and began to decline after the 12 th immunization. For $\mathrm{IgG}_{2}$, no increase in the antibody response was observed until the fifth immunization was administered, when serum anti-J5 $E$. coli $\mathrm{IgG}_{2}$ antibodies rose significantly $(\mathrm{P}<0.02)$ above the preimmunization level (Figure 3 ). The $\mathrm{IgG}_{2}$ response continued to increase until the 11th immunization, after which it reached a plateau.

\section{Isotype Specific Anti-J5 E. coli Antibody Endpoint Titers}

Preimmunization sera contained low but detectable titers of naturally occurring anti-J5 $E$. coli antibodies for all 3 isotypes (Figure 4). Of the selected samples analyzed, titers only reached levels that were significantly higher $(P<0.005)$ than preimmunization after the sixth dose of J5 bacterin was administered, and remained high through the 12 th immunization.

\section{Isotype-Specific Cross Reactivity Determined by ELISA}

As evidenced by increased OD values, cross reactivity of IgM antibodies rose above preimmunization reactivity after the sixth immunization for Serratia spp., Pseudomonas ssp., and Klebsiella spp. $(P<0.01)$, after the ninth immunization for $S$. typhimurium and $E$. coli $487(P<0.01)$, and after the 12th immunization for $S$. newport $(P<0.01)$ (top panel of Figure 5 ). Cross reactivity of IgM with LPS and lipid A was low and did not increase $(P>0.10)$ as the number of immunizations increased (bottom panel of Figure 5). Cross reactivity of $\mathrm{IgG}_{1}$ antibodies increased significantly $(P<0.01)$ above preimmunization following the sixth immunization for all gram-negative bacteria tested, except for $E$. coli 487 , which only required 3 immunizations $(P<0.001)$, and $S$. newport, which required 9 immunizations $(P<0.05$, top panel of Figure 6). Cross reactivity of $\operatorname{IgG}_{1}$ with LPS and lipid A was low and did not increase $(P>0.10)$ as the number of immunizations increased (bottom panel of Figure 6). Cross reactivity of $\mathrm{IgG}_{2}$ antibodies in-
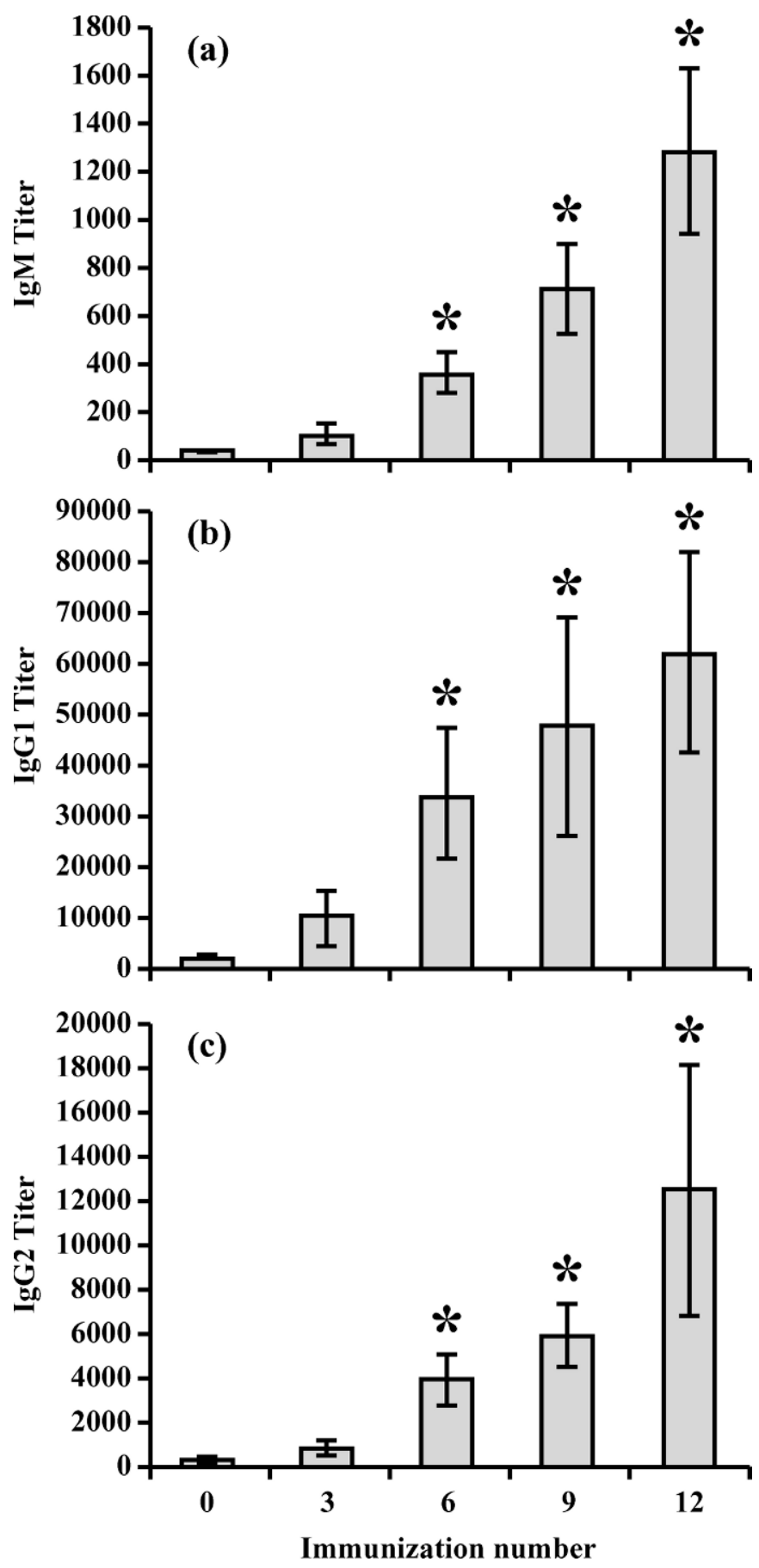

Figure 4. Mean ( \pm SEM) isotype-specific anti-J5 Escherichia coli $\operatorname{IgM}(\mathrm{a}), \operatorname{IgG}_{1}$ (b), and $\operatorname{IgG}_{2}$ (c) antibody titers in selected sera from J5-hyperimmunized Holstein steers. Sera were from $6 \mathrm{~d}$ post each immunization. *Postimmunization titers different than preimmunization titer (immunization number 0 ) at $P<0.005$.

creased significantly $(P<0.01)$ after the 6 th immunization compared with preimmunization for all gram-negative bacteria tested (top panel of Figure 7). As with IgM and $\mathrm{IgG}_{1}$, cross reactivity of $\operatorname{IgG}_{2}$ with LPS and lipid A 

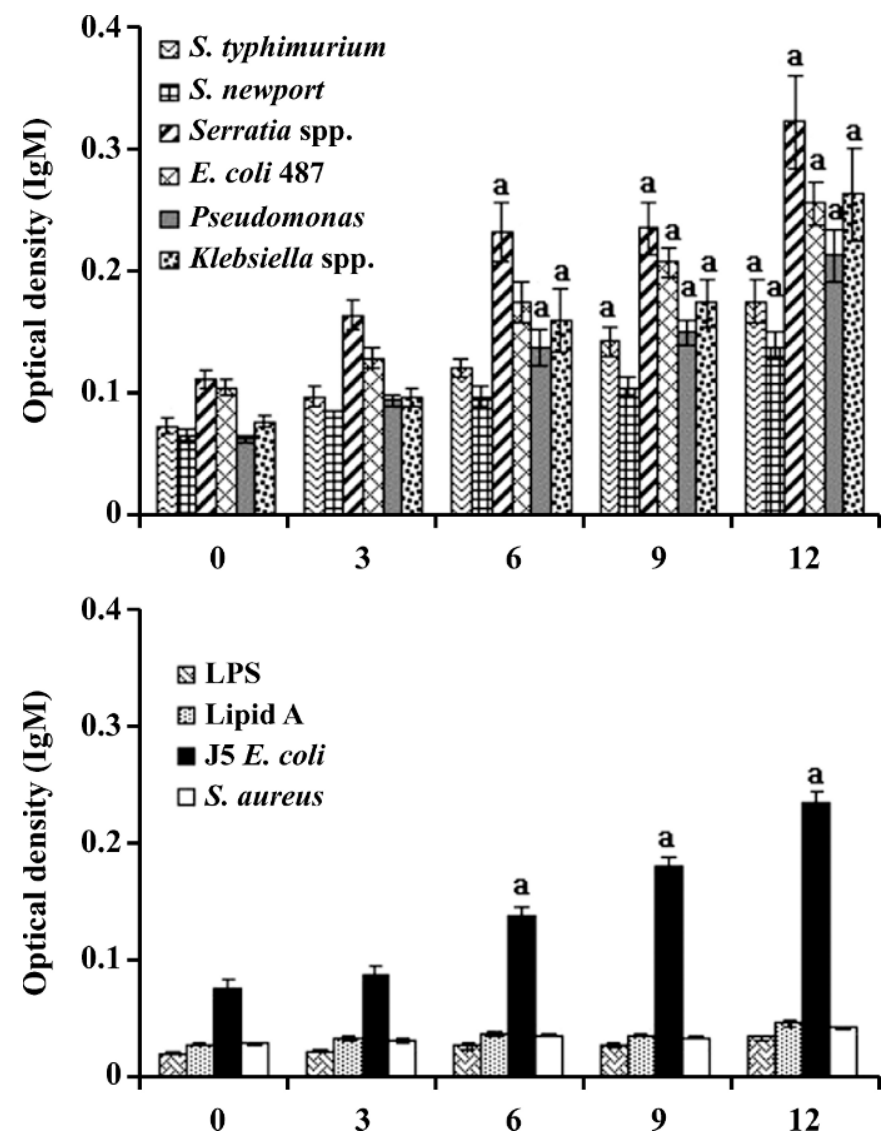

Figure 5. Cross-reactivity of serum IgM antibodies to heterologous gram-negative bacteria. Data are presented as mean optical densities $(\mathrm{OD} \pm \mathrm{SEM})$ within $\mathrm{J5}$ immunization number, and represent antiJ5 IgM antibody cross reactivity against different test antigens, with J5 Escherichia coli antigen as a positive control and Staphylococcus aureus as the negative control. Test antigens included Staphylococcus typhimurium, Staphylococcus newport, Serratia spp., E. coli 487, Pseudomonas spp., and Klebsiella spp. ${ }^{\text {a }}$ Indicates that cross reactivity was significantly higher than preimmunization at $P<0.01$.

did not increase $(P>0.10)$ as the number of immunizations increased (bottom panel of Figure 7). No cross reactivity of any antibody isotype with the $S$. aureus negative control was ever observed.

\section{Isotype-Specific Cross Reactivity Observed by Immunoblotting}

Immunoblot analysis of antigens present in crude lysates of heterologous gram-negative bacteria recognized by $\operatorname{IgM}, \operatorname{IgG}_{1}$, and $\mathrm{IgG}_{2}$ antibodies present in $\mathrm{J} 5$ immune sera demonstrated 3 key points (Figure 8). First, broad cross reactivity of all 3 antibody isotypes for large antigens (34 to $40 \mathrm{kDa}$; left panels of Figure 8) and small antigens (6 to $10 \mathrm{kDa}$; right panels of Figure 8) was observed. Second, at least some isotype switching in response to J5 hyperimmunization must
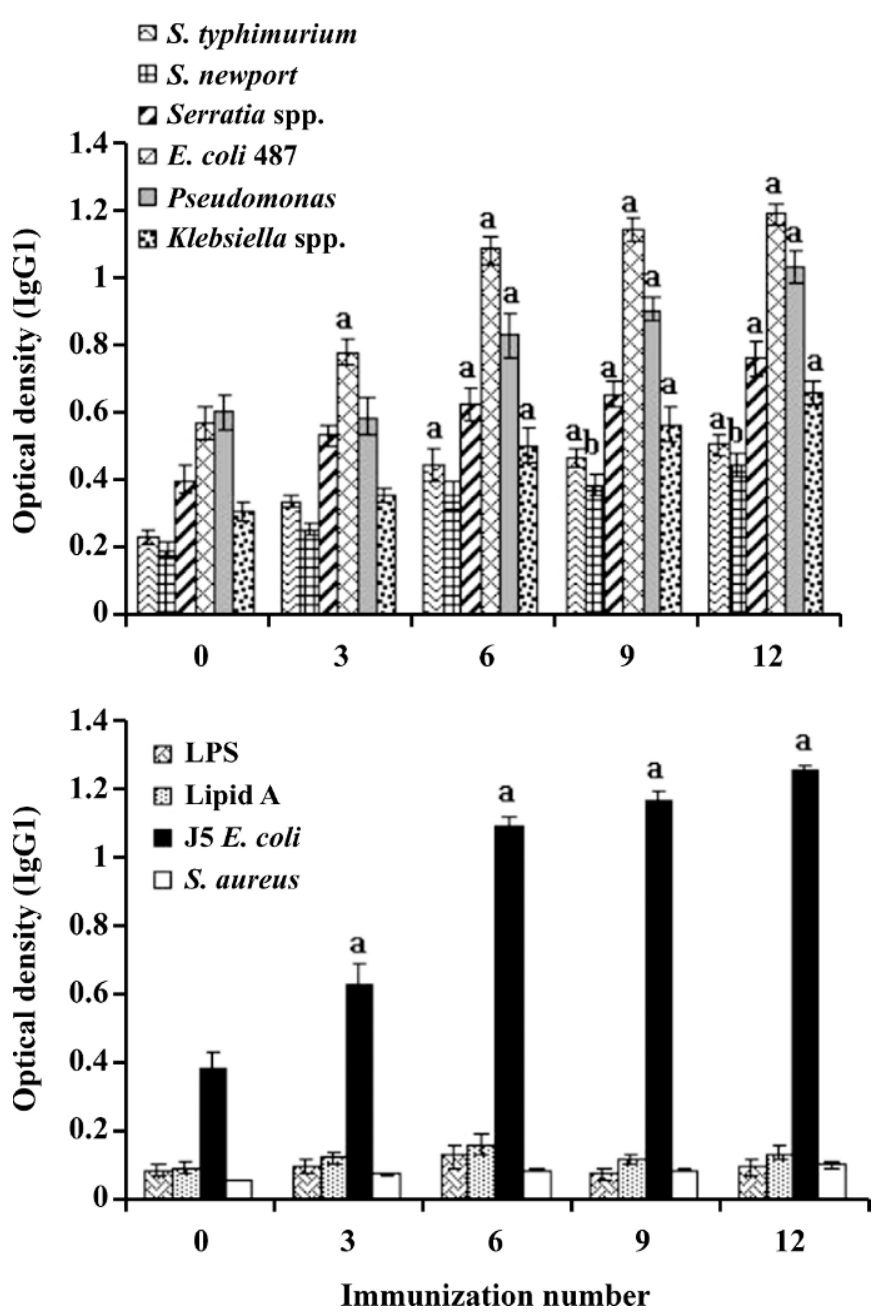

Figure 6. Cross-reactivity of serum $\mathrm{IgG}_{1}$ antibodies to heterologous gram-negative bacteria. Data are presented as mean optical densities $(\mathrm{OD} \pm \mathrm{SEM})$ within $\mathrm{J} 5$ immunization number, and represents anti-J5 IgG 1 antibody cross reactivity against different test antigens, with J5 Escherichia coli antigen as a positive control and Staphylococcus aureus as the negative control. Test antigens included Staphylococcus typhimurium, Staphylococcus newport, Serratia spp., E. coli 487, Pseudomonas spp., and Klebsiella spp. ${ }^{\text {a Indicates that }}$ cross reactivity was significantly higher than preimmunization at $P$ $<0.01$ and ${ }^{\mathrm{b}}$ at $P<0.05$.

have occurred because IgM and $\mathrm{IgG}_{1}$ recognition of the 34 to $40 \mathrm{kDa}$ antigens disappeared between the 3rd and 9th immunizations (left panels of Figure 8). On the other hand, $\mathrm{IgG}_{2}$ recognition of these same antigens remained strong between immunization numbers 3 and 9. Finally, $\operatorname{IgG}_{1^{-}}$and $\operatorname{IgG}_{2}$-specific antibody responses against smaller (6 to $10 \mathrm{kDa}$ ) antigens appeared to be especially responsive to hyperimmunization because these were negligible in third immunization serum but pronounced in ninth immunization serum (right panels of Figure 8). No cross reactivity of any antibody isotype with antigens $S$. aureus was observed. 

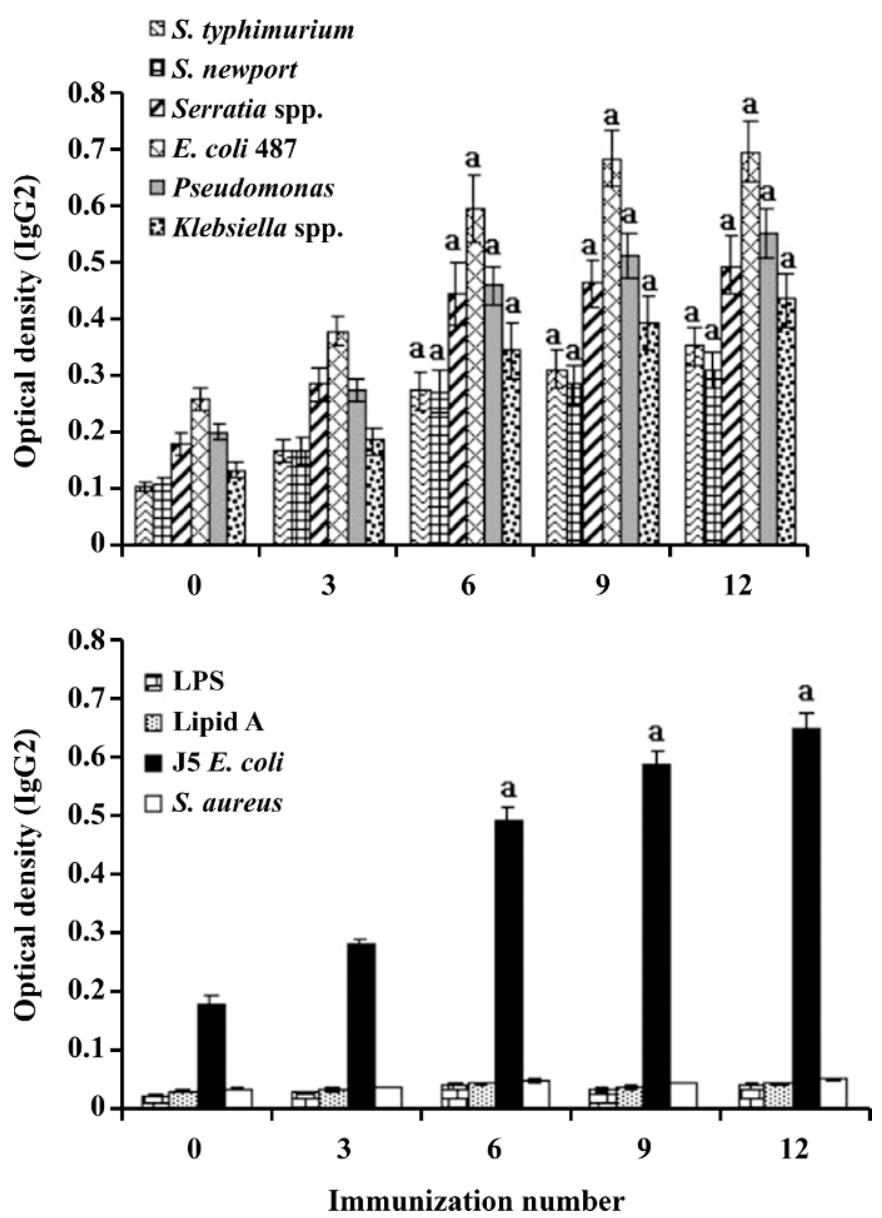

Figure 7. Cross reactivity of serum $\mathrm{IgG}_{2}$ antibodies to heterologous gram-negative bacteria. Data are presented as mean optical densities $(\mathrm{OD} \pm \mathrm{SEM})$ within $\mathrm{J} 5$ immunization number, and represents anti$\mathrm{J} 5 \mathrm{IgG}_{2}$ antibody cross reactivity against different test antigens, with J5 Escherichia coli antigen as a positive control and Staphylococcus aureus as the negative control. Test antigens included Staphylococcus typhimurium, Staphylococcus newport, Serratia spp., E. coli 487,

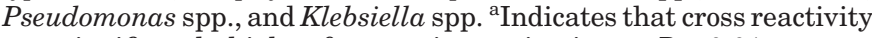
was significantly higher from preimmunization at $P<0.01$.

\section{DISCUSSION}

In our study, hyperimmunization of cattle with a commercial J5 E. coli bacterin increased isotype-specific antibody responses, titers and, for some antigens, cross reactivity to heterologous gram-negative bacteria, especially when compared to the naturally occurring antibodies present before immunizations were initiated and after 3 immunizations were given. Although 2 to 3 doses of $\mathrm{J} 5$ bacterin were sufficient to increase serum antiJ5 E. coli IgM and IgG $_{1}$ antibody response profiles above levels present at preimmunization, more than 3 doses were needed to increase anti-J5 E. coli endpoint titers and cross reactivity above background for all 3 isotypes studied. Based on endpoint titer data and antibody cross reactivity to heterologous whole cell gram-negative bacteria, the results of the current study indicate that additional booster doses above the 2 currently recommended may be required to increase cross reactive $\mathrm{IgG}_{1}$ and especially $\mathrm{IgG}_{2}$ antibody responses in cattle. Cross reactivity appeared to be specific for gram-negative bacteria because none was observed with $S$. aureus (Figures 5 to 7), as was shown in a previous study (Tyler et al., 1991). Also consistent with previous observations (Gonzalez et al., 1989), we found antibodies in preimmune sera, especially $\operatorname{IgG}_{1}$, with some cross reactivity against whole cell $E$. coli and Pseudomonas. This might be explained through natural exposure of animals to environmental gram-negatives, especially bacteria present in the digestive tract.

Antibodies of the IgM isotype are the first to be produced and secreted by naïve B cells during primary exposure to antigens. With successive exposures to the same antigen, IgM-to-IgG ${ }_{1}$ or to-IgG $\mathrm{I}_{2}$ isotype switching can occur in responding $\mathrm{B}$ cell clones, effectively shutting down production of IgM by these clones and resulting in massive synthesis and secretion of either $\mathrm{IgG}_{1}$ or $\mathrm{IgG}_{2}$. The classical humoral immune response occurs via a specific class of B cells that are characterized by lack of surface CD5 expression (i.e., CD5 ${ }^{-}$B cells) and requires stimulation by specific cytokines elaborated from antigen-reactive helper $\mathrm{T}$ cells to stimulate isotype switching. The cytokines interleukin (IL)4, IL-5, and IL-6 are primarily responsible for promoting isotype switching from IgM-to-IgG ${ }_{1}$ in bovine CD5 ${ }^{-}$ B cells (Estes, 1996; Haas and Estes, 2000). These cytokines are elaborated from helper $\mathrm{T}$ cells known as type 2 cells, or $\mathrm{T}_{\mathrm{H}} 2$. The $\mathrm{T}_{\mathrm{H}} 2$ response is directed specifically towards antibody production against certain protein antigens, and in the case of $\mathrm{IgG}_{1}$ antibody production, becomes critical for blocking bacterial colonization and toxins at sites of tissue infection (Butler, 1998). A $\mathrm{T}_{\mathrm{H}}$ 2-like response must have occurred during the initial phase of our J5 hyperimmunization protocol because the magnitude of the serum anti-J5 E. coli IgM response profile did not change between immunizations 3 and 6 (Figures 1 and 4), during which time there was a remarkable increase in the magnitude of the $\mathrm{IgG}_{1}$ response (Figures 2 and 4). After the sixth immunization, additional isotype switching in existing IgM- and (or) $\mathrm{IgG}_{1}$-producing B cells must have occurred because a gradual but continuous increase in the magnitude of the J5 E. coli-specific serum $\mathrm{IgG}_{2}$ antibody response was observed (Figures 3 and 4). Also, immunoblot analysis showed that IgM and $\mathrm{IgG}_{1}$ recognition of 34 to $40 \mathrm{kDa}$ antigens in J5 E. coli and heterologous gram-negative bacteria lysates dwindled between immunizations 3 and 9 , while $\mathrm{IgG}_{2}$ recognition of these antigens remained strong and increased remarkably for some 

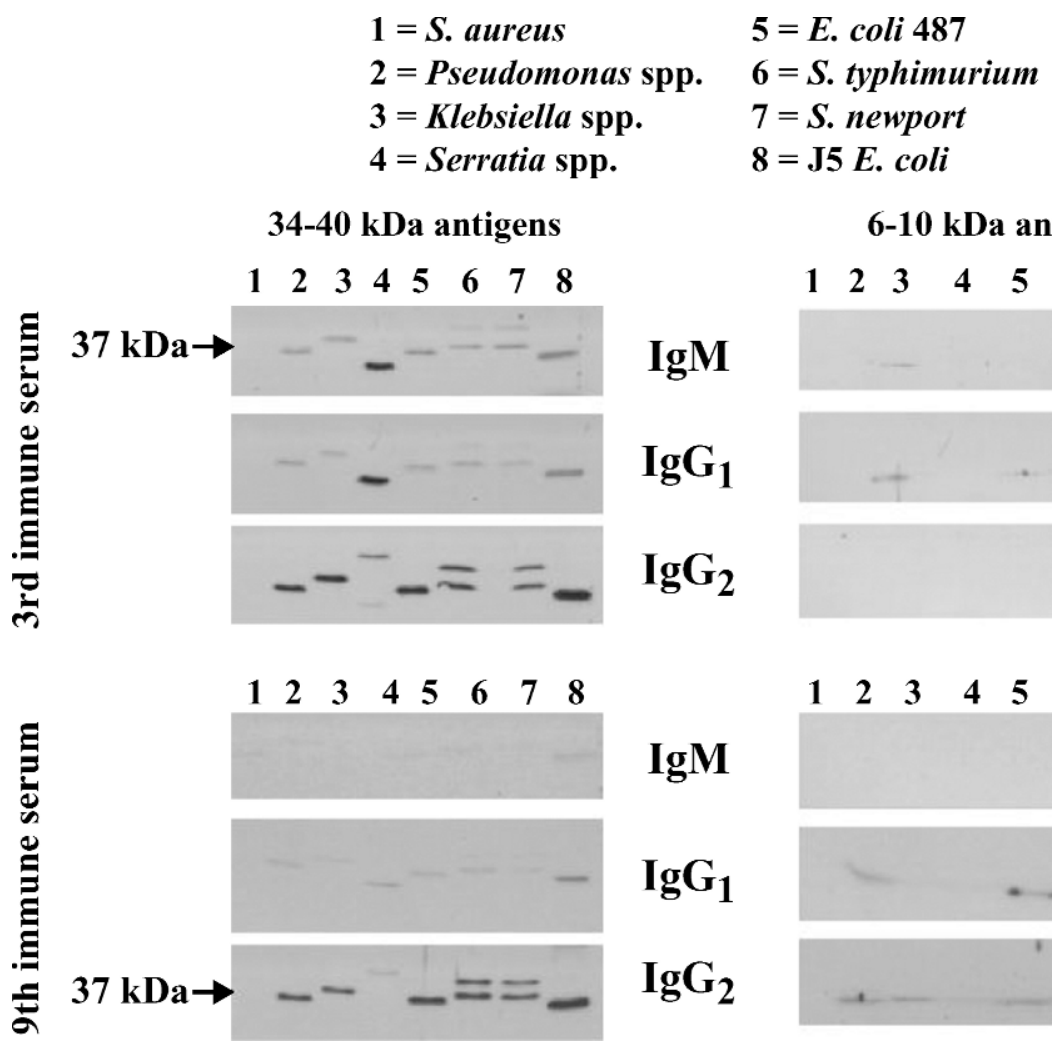

6-10 kDa antigens
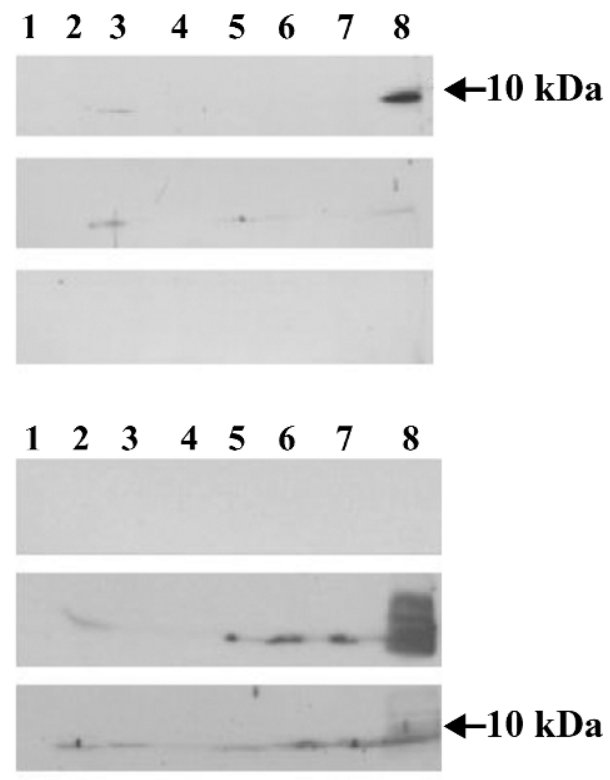

Figure 8. Immunoblot analysis of cross reactivity of $\operatorname{IgM}, \operatorname{IgG}_{1}$, and $\operatorname{IgG}_{2}$ antibodies present in third and ninth J5 immune sera with large (34 to $40 \mathrm{kDa}$; left panels) and small (6 to $10 \mathrm{kDa}$; right panels) antigens contained in crude lysates of heterologous gram-negative bacteria. Staphylococcus aureus lysate (lane 1) was used as a negative control and J5 E. coli lysate (lane 8) as a positive control. Test lysates included Pseudomonas spp. (lane 2), Klebsiella spp. (lane 3), Serratia spp. (lane 4), E. coli 487 (lane 5), Staphylococcus typhimurium (lane 6), and Staphylococcus newport. (lane 7).

smaller (6 to $10 \mathrm{kDa}$ ) antigens (Figure 8). Interferongamma $(\mathbf{I F N}-\gamma)$ is primarily responsible for $\mathrm{IgG}_{2}$ isotype switching in bovine CD5 ${ }^{-} \mathrm{B}$ cells (Estes, 1996) and is elaborated from helper $\mathrm{T}$ cells known as type 1 cells, or $\mathrm{T}_{\mathrm{H}} 1$. Our results suggested that 6 or more doses of J5 bacterin may be required to stimulate strong $\mathrm{T}_{\mathrm{H}} 1$ responses in cattle because anti-J5 E. coli IgG $_{2}$ antibodies detected in our study animals did not differ between immunizations 1 to 5 (Figure 3 ). $\mathrm{T}_{\mathrm{H}} 1$ responses are critical to rapid immune defense against acute bacterial infections in cattle because $\mathrm{IgG}_{2}$ antibodies act as direct opsonins for efficient neutrophil phagocytosis of the pathogens and because IFN- $\gamma$ potently activates the neutrophils to kill bacteria that have been phagocytosed (reviewed by Burton and Erskine, 2003). Combined with the significantly enhanced cross reactivity of $\mathrm{IgG}_{2}$ antibodies in hyperimmune sera for all 6 heterologous gram-negative bacteria tested (Figure 7) and for 6 to $10 \mathrm{kDa}$ antigens present in lysates of these bacteria (right panels of Figure 8), we suggest that at least 6 doses of J5 bacterin may be needed to elicit strong $\mathrm{T}_{\mathrm{H}} 1$-based $\mathrm{IgG}_{2}$ immunity in vaccinated cattle.
None of the antibody isotypes in J5 hyperimmune sera had marked cross reactivity with purified LPS or lipid A in ELISA (Figures 5 to 7). In other studies, antibodies elicited in rabbits with fewer immunizations also showed little cross reactivity with LPS or lipid A (Siber et al., 1985; Warren et al., 1987; Hellman et al., 1997). Core antigens are suggested to be important inducers of protective antibodies in J5-immunized animals (Baumgartner et al., 1987; Pollack et al., 1989; Aydintug et al., 1989; Tyler et al., 1991, 1992). While it is possible that ELISA is not an optimal platform to detect antibody reactivity with purified LPS or lipid A, it is also possible that assumptions of ready recognition and responsiveness of the immune system to these exposed core antigens on J5 E. coli are incorrect. It has been suggested that apparent binding by antibodies, raised from J5 $E$. coli immunizations, to LPS may be, in part, a result of LPS-outer membrane protein (OMP) complexes released by bacterial cell walls (Freudenberg et al., 1992). Immunoblot analysis revealed that antiserum raised from 11 immunizations of J5 E. coli in rabbits contain high titers of IgG antibodies that bind to 
at least 3 major OMP, but not LPS (Hellman et al., 1997). In a model of bacterial sepsis, 3 conserved OMPLPS complexes were captured from septic rat blood by O-chain-specific anti-LPS IgG (Hellman, et al., 2000a). The OMP have been identified as outer membrane protein $\mathrm{A}$, of $35 \mathrm{kDa}$, peptidoglycan-associated lipoprotein, of $18 \mathrm{kDa}$, and murein lipoprotein of 5 to $9 \mathrm{kDa}$ (Hellman et al., 2000b). Thus, J5 E. coli immunization may offer protection, in part, from production of IgG antibodies that bind to OMP released during bacterial sepsis.

Unlike protein antigens that induce specific $\mathrm{T}_{\mathrm{H}} 1$ or $\mathrm{T}_{\mathrm{H}} 2$ antibody responses in reactive $\mathrm{CD}^{-} \mathrm{B}$ cells, nonprotein LPS and lipid A antigens require a different type of immune recognition that can stimulate another class of B cells expressing CD5 on their plasma membranes (i.e., $\mathrm{CD}^{+} \mathrm{B}$ cells). $\mathrm{CD}^{+} \mathrm{B}$ cells do not require help from $\mathrm{T}$ cells and produce mainly IgM antibodies with little to no isotype switching (Hayakawa et al., 1984; Kantor 1991; Mond et al., 1995; Haas and Estes, 2000). During some infections, $\mathrm{CD}^{+} \mathrm{B}$ cells can account for up to $30 \%$ of bovine peripheral blood lymphocytes and lead to very high titers of pathogen-specific serum IgM antibodies with a notable lack of $\mathrm{IgG}_{1}$ or $\mathrm{IgG}_{2}$ antibody responses (Nassens and Williams, 1992; Meirom et al., 1993; Buza et al., 1997; Haas and Estes, 2000). While IgM-producing $\mathrm{CD}^{+} \mathrm{B}$ cells may have responded to LPS or lipid A in our J5 vaccinated steers, this response was not detectable in serum using our ELISA. Instead, we detected primarily $\operatorname{IgG}_{1}$ and $\mathrm{IgG}_{2}$ antibody responses in hyperimmune sera that were cross reactive with whole gram-negative bacteria and certain 34 to $40 \mathrm{kDa}$ and 6 to $10 \mathrm{kDa}$ antigens but not with LPS or lipid A, suggesting that the majority of J5-responsive $\mathrm{B}$ cells were $\mathrm{CD5}^{-}$and responded to protein antigens contained in the bacterin (Hellman et al., 1997). If future studies show this to be true, J5 vaccines may prove more efficacious if modified to include these immunogenic proteins in such a way that they rapidly stimulate production of cross protective $\mathrm{IgG}_{1}$ and $\mathrm{IgG}_{2}$ antibodies.

\section{CONCLUSION}

Hyperimmunization of steers with a J5 E. coli bacterin increased serum responses of IgM IgG 1 , and $\mathrm{IgG}_{2}$ compared with preimmunization levels. However, little or no increase was observed in the $\mathrm{IgG}_{2}$ response until after the fifth immunization. Increases in cross-reactive antibodies to heterologous gram-negative bacteria were apparent for all 3 isotypes, but significant only after 6 immunizations. Thus, multiple immunizations of this bacterin, beyond the labeled use of 3 doses, were needed to induce significant responses for certain isoptypes and cross-reactive antibodies. It is unknown, however, whether this observation would apply to other commer- cially available gram-negative bacterins, including core-antigen varieties. No cross reactivity with LPS or lipid A was observed for any antibody isotype or any immunization period studied. We suggest that isotype switching, as indicated by increased $\mathrm{IgG}_{2}$ responses in hyperimmunized steers, could be an important indicator of profound changes in antigen recognition and presentation elicited by multiple dosing of gram-negative core antigen bacterins.

\section{ACKNOWLEDGMENTS}

Funding for this project was provided by the Royal Thai Government (AC), the Michigan Agricultural Experiment Station and the Michigan Animal Initiative Coalition (JLB and RJE), and Pharmacia Animal Health (RJE and JLB). The authors thank Mr. and Mrs. J. Powell for use of the steers during this study.

\section{REFERENCES}

Aydintug, M. K., T. J. Inzana, T. Letonja, W. C. Davis, and L. B. Corbeil. 1989. Cross-reactivity of monoclonal antibodies to Escherichia coli J5 with heterologous gram-negative bacteria and extracted lipopolysaccharides. J. Infect. Dis. 160:846-857.

Baumgartner, J. D., T. X. O'Brien, T. N. Kirkland, M. P. Glauser, and E. J. Ziegler. 1987. Demonstration of cross-reactive antibodies to smooth gram-negative bacteria in antiserum to Escherichia coli J5. J. Infect. Dis. 156:136-143.

Burton, J. L., B. A. Mallard, and D. N. Mowat. 1993. Effects of supplemental chromium on immune responses of periparturient and early lactation dairy cows. J. Anim. Sci. 71:1532-1539.

Burton, J. L., and R. J. Erskine. 2003. Mastitis and immunity: Some new ideas for an old disease. Vet. Clin. North Am. Food Anim. Pract. 19:1-45.

Butler, J. E. 1998. Immunoglobulin diversity, B-cell and antibody repertoire development in large farm animals. Rev. Sci. Technol. $17: 43-70$.

Buza, J., M. Sileghem, P. Gwasika, and J. Naessens. 1997. CD5 ${ }^{+}$B lymphocytes are the main source of antibodies reactive with nonparasite antigens in Trypanosoma congolense-infected cattle. Immunology 92:226-233.

Cullor, J. S. 1991. The Escherichia coli J5 vaccine: Investigating a new tool to combat coliform mastitis. Vet. Med. 86:836-844.

Estes, M. D. 1996. Differentiation of B cells in the bovine: Role of cytokines in immunoglobulin isotype expression. Vet. Immunol. Immunopathol. 54:61-67.

Freudenburg, M. A., A. Fornsguard, I. Mitov, and C. Galanos. 1989. ELISA for lipid A, lipopolysaccharide and other hydrophobic antigens. Infection 17:322-328.

Freudenberg M. A., U. Meier-Dieter, T. Staehelin, and C. Galanos. 1992. Analysis of LPS released from Salmonella abortus equi in human serum. Microb. Pathol. 10:93-104.

Gonzalez, R. N., J. S. Cullor, D. E. Jasper, T. B. Farver, R. B. Bushness, and M. N. Oliver. 1989. Prevention of clinical coliform mastitis in dairy cows by a mutant Escherichia coli vaccine. Can. J. Vet. Res. 53:301-305.

Haas, K. M., and D. M. Estes. 2000. Activation of bovine B cells via surface immunoglobulin M cross-linking or CD40 ligation results in different B-cell phenotypes. Immunology 99:272-278.

Harlow, E., and D. Lane. 1999. Pages 234-235, 313 in Using Antibodies, a Laboratory Manual. Cold Spring Harbor Laboratory Press. New York, NY.

Hayakawa, K., R. R. Hardy, M. Honda, L. A. Herzenberg, A. D. Steinberg, and L. A. Herzenberg. 1984. Ly-1 B cells: Functionally 
distinct lymphocytes that secrete IgM autoantibodies, Proc. Natl. Acad. Sci. USA 81:2494-2498.

Hellman, J., E. M. Zanzot, P. M. Loiselle, S. F. Amato, K. M. Black, Y. Ge, J. T. Kurnick, and H. S. Warren. 1997. Antiserum against Escherichia coli J5 contains antibodies reactive with outer membrane proteins of heterologous gram-negative bacteria. J. Infect. Dis. 176:1260-1268.

Hellman, J., E. M. Zanzot, P. M. Loiselle, S. F. Amato, K. M. Black, Y. Ge, J. T. Kurnick, and H. S. Warren. 2000a. Antiserum against Escherichia coli J5 contains antibodies reactive with outer membrane proteins of heterologous Gram-negative bacteria. J. Infect. Dis. 176:1260-1268.

Hellman, J., P. M. Loiselle, M. M. Tehan, J. E. Allaire, L. A. Boyle, J. T. Kurnick, D. M. Andrews, K. S. Kim, and H. S. Warren. 2000b. Outer membrane protein A, peptidoglycan-associated lipoprotein, and murein lipoprotein are released by Escherichia coli bacteria into serum. Infect. Immun. 68:2566-2572.

Hill, A. W. 1991. Vaccination of cows with rough Escherichia coli mutants fails to protect against experimental intramammary bacterial challenge. Vet. Res. Commun. 15:7-16.

Kantor, A. 1991. A new nomenclature of B cells. Immunol. Today 12:388-391.

Kehrli, M. E., Jr., and J. A. Harp. 2001. Immunity in the mammary gland. Vet. Clin. North Am. Food Anim. Pract. 17:495-516.

McGuire, T. C., A. J. Musoke, and T. Kurtti. 1987. Functional properties of bovine $\mathrm{IgG}_{1}$ and $\mathrm{IgG}_{2}$ : interaction with complement, macrophages, neutrophils and skin. Immunology 38:249-256.

Meirom, R., J. Brenner, and Z. Trainin. 1993. BLV-infected lymphocytes exhibit two patterns of expression as determined by Ig and CD5 markers. Vet. Immunol. Immunopathol. 36:179-186.

Mond, J. J., A. Lees, and C. A. Snapper. 1995. T cell-independent antigen type 2. Annu. Rev. Immunol. 13:655-692.

Nassens, J., and D. J. L. Williams. 1992. Characterization and measurement of $\mathrm{CD}^{+} \mathrm{B}$ cells in normal and Trypanosoma congolenseinfected cattle. Eur. J. Immunol. 22:1713-1718.
Pollack, N., J. K. Chia, N. L. Koles, M. Miller, and G. Guelde. 1989. Specificity and cross-reactivity of monoclonal antibodies reactive with the core and lipid A regions of bacterial lipopolysaccharide. J. Infect. Dis. 159:168-188.

Promega. 1996. Protocols and application guide, third edition. Promega Corporation (Catalogue \#P1610). 255 and 281.

SAS/STAT User's Guide. (1999) Version 8, SAS Institute Inc., Cary, NC.

Siber, G. R., S. A. Kania, and H. S. Warren. 1985. Cross-reactivity of rabbit antibodies to lipopolysaccharides of Escherichia coli J5 and other gram-negative bacteria. J. Infect. Dis. 152:954-964.

Tomita, G. M., C. H. Ray, S. C. Nickerson, W. E. Owens, and G. F Gallo. 2000. A comparison of two commercially available Escherichia coli J5 vaccines against $E$. coli intramammary challenge. J. Dairy Sci. 83:2276-2281.

Tomita, G. M., D. A. Todhunter, J. S. Hogan, and K. L. Smith. 1995. Antigenic crossreactivity and lipopolysaccharide neutralization properties of bovine immunoglobulin G. J. Dairy Sci. 78:27452752.

Tyler, J., H. Spears, J. Cullor, W. Smith, R. Nelson, and J. Martin. 1991. Antigenic homology among gram-negative organisms isolated from cattle with clinical mastitis. J. Dairy Sci. 74:12351242.

Tyler, J. W., H. Spears, and R. Nelson. 1992. Antigenic homology of endotoxin with a coliform mastitis vaccine strain, Escherichia coli 0111:B4 (J5). J Dairy Sci. 75:1821-1825.

Tyler, J. W., J. S. Cullor, and J. D. Dellinger. 1990a. Cross reactive affinity purification of immunoglobulin recognizing common gram-negative bacterial core antigens. J. Immunol. Methods 129:221-226.

Tyler, J. W., J. S. Cullor, S. J. Spier, and B. P. Smith. 1990b. Immunity targeting common core antigens of gram-negative bacteria. J. Intern. Med. 4:17-25.

Warren, H. S., T. J. Novitsky, A. Bucklin, S. A. Kania, and G. R. Siber. 1987. Endotoxin neutralization with rabbit antisera to Escherichia coli J5 and other gram-negative bacteria. Infection $55: 668-673$. 